University of Nebraska - Lincoln

DigitalCommons@University of Nebraska - Lincoln

Egyptian textiles and their production: 'word' and 'object'

Centre for Textile Research

$3-2-2020$

\title{
Tackling the technical history of the textiles of El-Deir, Kharga Oasis, the Western Desert of Egypt
}

Fleur Letellier-Willemin

Limoges University

Follow this and additional works at: https://digitalcommons.unl.edu/egyptextiles

Part of the Africana Studies Commons, African Languages and Societies Commons, Classical Archaeology and Art History Commons, Fiber, Textile, and Weaving Arts Commons, History of Art, Architecture, and Archaeology Commons, and the History of Science, Technology, and Medicine Commons

Letellier-Willemin, Fleur, "Tackling the technical history of the textiles of El-Deir, Kharga Oasis, the Western Desert of Egypt" (2020). Egyptian textiles and their production: 'word' and 'object'. 4.

https://digitalcommons.unl.edu/egyptextiles/4

This Article is brought to you for free and open access by the Centre for Textile Research at DigitalCommons@University of Nebraska - Lincoln. It has been accepted for inclusion in Egyptian textiles and their production: 'word' and 'object' by an authorized administrator of DigitalCommons@University of Nebraska - Lincoln. 


\title{
Tackling the technical history of the textiles of El-Deir, Kharga Oasis, the Western Desert of Egypt ${ }^{1}$
}

\author{
Fleur Letellier-Willemin
}

The site of El-Deir is situated north of Kharga in the "Great Oasis" of the Egyptian Western Desert (fig. 1). ${ }^{2}$ The site was occupied between the $6^{\text {th }}$ century BC and the $6^{\text {th }}$ century AD. A complex history emerged with the influence of many cultures: Persian, Greek, Roman and early Christian. Archaeological finds in both El-Deir and the oasis itself (the site of Dush and the temple of Darius in Hibis, a city north of Kharga) confirm that the Great Oasis was a wealthy region. ${ }^{3}$ This is also substantiated by texts from Ain Manawir and Dakhleh. ${ }^{4}$ The presence of an artesian aquifer, a great economic asset, further underpinned the prosperity of the area, which was a crossroads for numerous routes from the earliest dynasties. ${ }^{5}$

\section{The specific nature of textiles from El-Deir}

There are currently three different sources of textiles on the site (fig. 2): the six cemeteries (five polytheistic and one Christian), the workshop of the embalmers, and the Roman fortress with adjacent temple. Most of the textiles have been found in a funerary context.

The study of the textiles takes place within an oasis, a circumscribed setting with a specific geography and climate, and over a long continuous period. Such conditions are favourable for emphasising traditions and changes.

Before briefly mentioning the material from El-Deir, we feel it is important to underline that comparisons with other textile studies are difficult. The majority of the necropoleis of the site are Ptolemaic and very few studies have concentrated on this period. In consequence, any possible comparisons must be made with recourse to Pharaonic textiles. On the other hand, the examples of textiles retrieved from the soundings in the fortress can be easily placed due to studies conducted in the Eastern Desert. Likewise, material from the Christian cemetery finds parallels in the numerous sites in Egypt that date to the Byzantine era.

Technical and aesthetic criteria of the textiles from the site are important for the study of the social status of the buried individuals and provide an assessment of the local standard of living. The study of textiles can also help in reconstructing, at least partially, the textile industry of the oasis. Textiles can also shed new light on religious, cultural and economic life. Lastly, they can serve as a comparative tool for other sites.

How does one deal with the diversity and quantity of textiles found in such a specific oasis site? Four hundred pieces of textile were selected in the field, entered into a

Published in Maria Mossakowska-Gaubert, ed., Egyptian Textiles and Their Production: 'Word' and 'Object' (Hellenistic, Roman and Byzantine Periods) (Lincoln, NE: Zea Books, 2020). doi 10.32873/unl.dc.zea.1081

\footnotetext{
1. The textile study of El-Deir is part of the French multidisciplinary mission to El-Deir, led by Dr Gaëlle Tallet, University of Limoges.

2. Wagner 1987, p. 124-128 and 131-134.

3. Reddé 1992; Hope \& Whitehouse 2003; Agut \& Moreno 2016, p. 520.

4. Chauveau 1996 ; Agut-Labordère 2014.

5. Tallet et al. 2012; Guédon 2012, p. 62-63.
} 


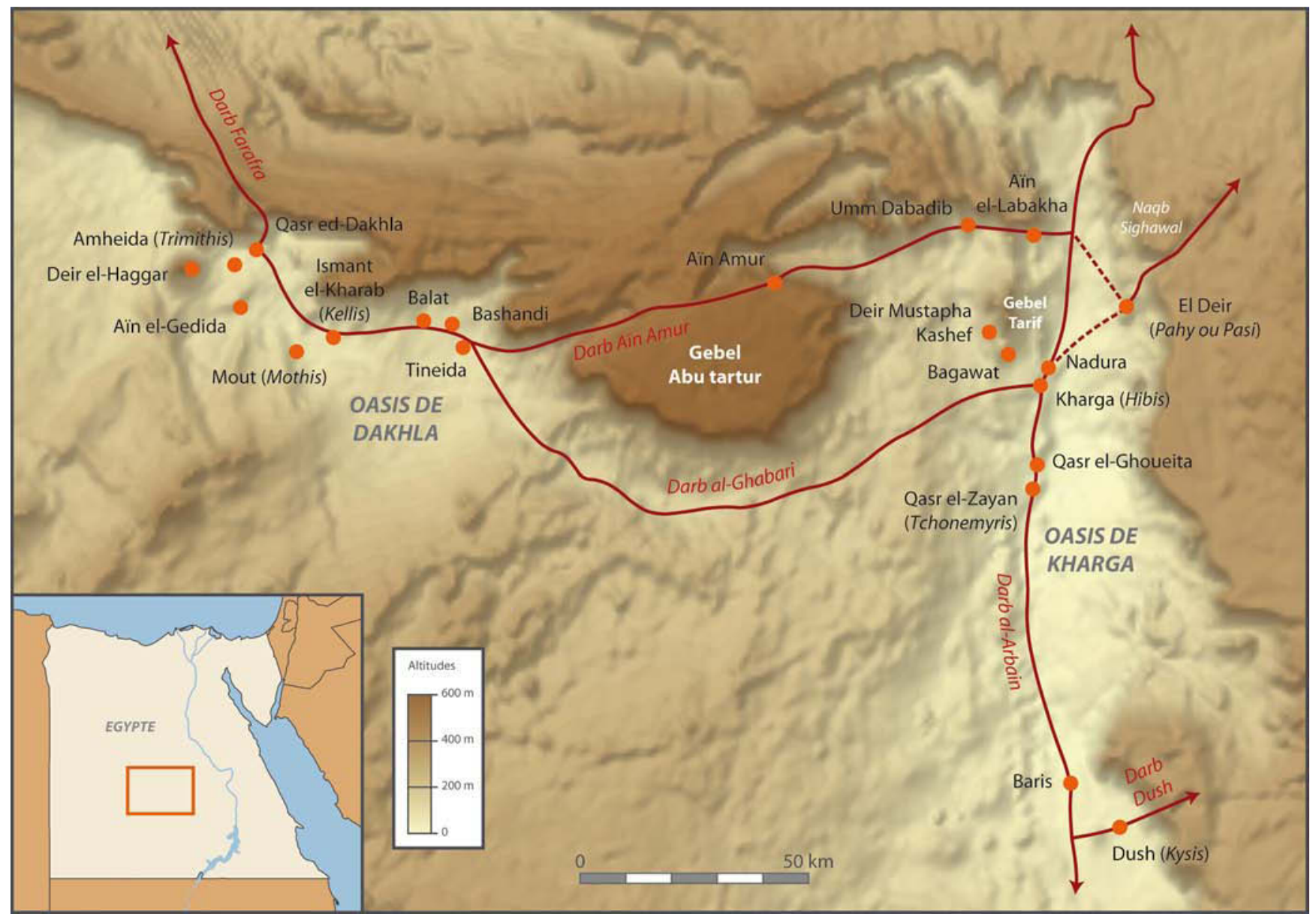

Figure 1. The Great Oasis: crossroads (Drawing (c) Mission archéologique d'El-Deir/ANR OASIS).

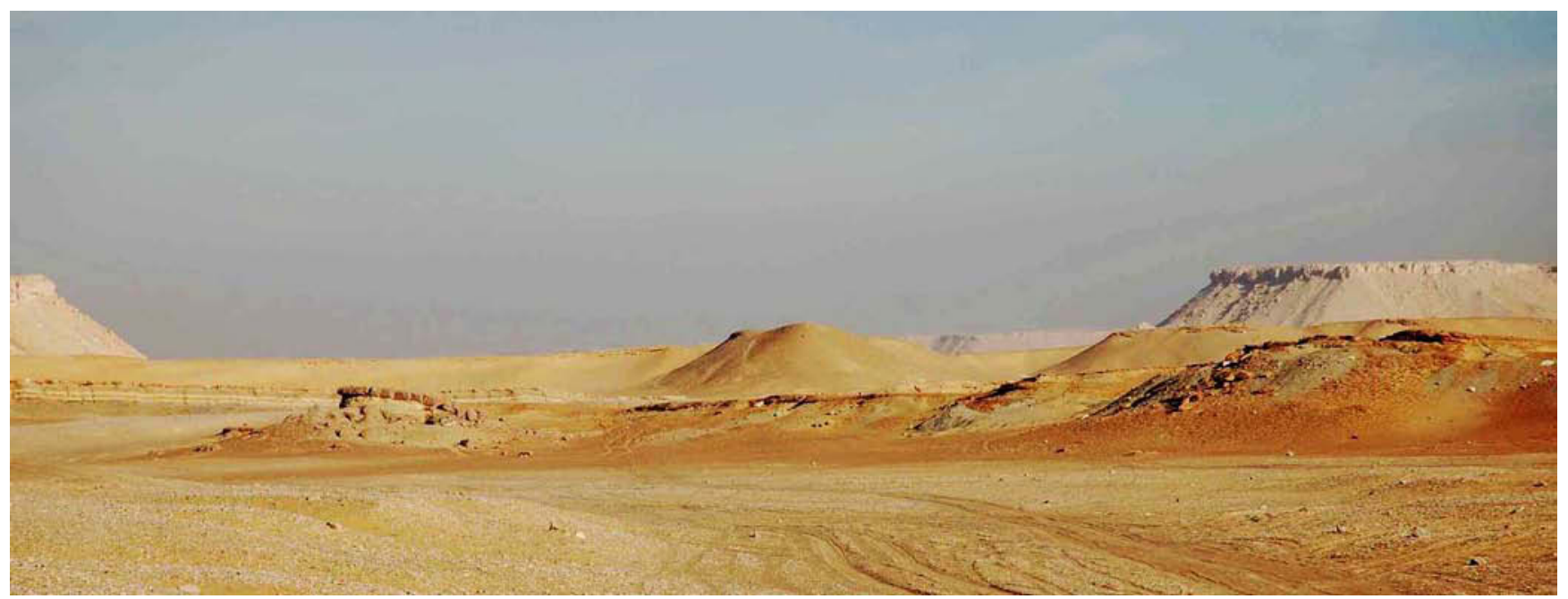

Figure 2. North, East and the so-called "Piton aux chiens" cemeteries: general view (Photo: Fleur Letellier-Willemin $\subset$ Mission archéologique d'El-Deir/ANR OASIS). 
database and then analysed. An essential step in the first instance was to choose, on-site, representative textiles according to quantity and quality, archaeological context, per individual, per tomb or en masse. These were in the great majority mere fragments, the site having been looted many times in the not too distant past. Once the textiles had been sorted, the second step involved a technical examination stretching from fibre to fabric, in order to shed light, for each, on the characteristics, the techniques used to transform them and, when possible, the tools used to do so.

Only a few examples, which illustrate the diversity of the site, will be presented in this article, while focus shall remain on the raw material. We have chosen to present, one by one, the three textile fibres found on the site: linen, cotton and wool.

\section{Linen}

Linen textiles were present everywhere on the site but most were found in the polytheistic cemeteries during of the examination of the human and dog mummies. These cemeteries are from the Ptolemaic period but they were used until the end of the $3^{\text {rd }}$ century $A D$, perhaps even during the $4^{\text {th }}$ century AD. Traditional Egyptian linen is very plain. The quality of the thread and the quality of the weaving are immediately noticeable in a plain cloth with little or no decoration. The Egyptian reference textile since the first dynasties is based upon a linen cloth of high quality thread and weaving.

The linen fibres from the site of El-Deir are generally long and regular. Only a few coarse textiles have been found and they have short and coarse threads.

Some undyed textiles appear as if they were flecked, a rare characteristic. The darkest fibres are completely unprocessed whereas the brightest fibres are rather decomposed and less ligneous. This was the result of a specific technical choice, although not limited to El-Deir since we also find such textiles elsewhere in the Nile Valley. ${ }^{6}$

The threads always present an S-twist. We cannot give statistics on splicing or spinning at El-Deir even if spinning easily predominates. Plied threads, with two S2s yarns, are not so rare. 7 Different categories of threads are defined by their regularity, diameter and twisting. The most common threads (about 44\%) have a diameter between 0.3 and $0.5 \mathrm{~cm}$, with an average twist of around 45 degrees. A few rare threads are $0.2 \mathrm{~cm}$ in diameter, which could mean they were made using a different process. ${ }^{8}$ The usual differences between warp and weft are respected although, sometimes, some weft yarns display a very high amount of twisting, more than the warp. This can be regarded as a choice because in traditional textiles (warp-faced tabbies) the warp was considered to be the strongest thread. ${ }^{9}$

The weaving shows only tabbies. In number, plain tabbies predominate very largely, followed by basket weave, then half-basket and balanced finally with a few rare tabbies with "floated threads". Knots are very often found in the weft and sometimes in the warp. Their number reflects the quality of the threads and/or the experience of the weaver with only a few errors noticed. The most frequent errors are short weft floats, which could suggest the use of a ground loom.

Another key characteristic of the flax from El-Deir is the density of the threads. The most common density is around 22 to 28 warp yarns per centimetre and eight to 12 weft yarns per centimetre. Textiles with 40 warp yarns per centimetre are not so rare. There are also a few textiles (bandages and shrouds) with 60 warp yarns per centimetre on human and dog mummies. A small quantity of coarse textiles was found as stuffing.

The selvedges are always plain and most of them are regular which means the weaver was experienced. Some selvedges are tightly packed to produce ribbing, another technical point. The so-called "Piton aux chiens" cemetery is where a bandage with a special funerary weaving of its two selvedges was found. It is the only one on the site and might belong to someone in the higher ranks of society.

The borders show different weavings made with different tools and thus are very important to identify. We can distinguish two categories: borders without fringes and borders with fringes (fig. 3). Weaving techniques may be different to produce each of them. For example, a border with fringes can be the beginning and end, or only the end, of a textile made on a horizontal or on a vertical twobeam loom.

When present, fringes reflect a fashion. For instance, a large quantity of textiles with long diverse fringes was found in the cemetery south of the site, whereas many woven looped fringes were found in the cemetery on the north side.

The study of hems underlines the use of Z2s threads. Many of them are carefully rolled. We can find different well-known, "classical", sewing patterns. One of them should be highlighted: it is used on the shoulders of Roman

\author{
6. Huber 2015, p. 18-19. \\ 7. Kemp \& Vogelsang-Eastwood 2001, p. 59. \\ 8. Cook \& Brennan 1990, p. 9. \\ 9. Oral communication with J. P. Wild \& S. Desrosiers. I thank them very much.
}




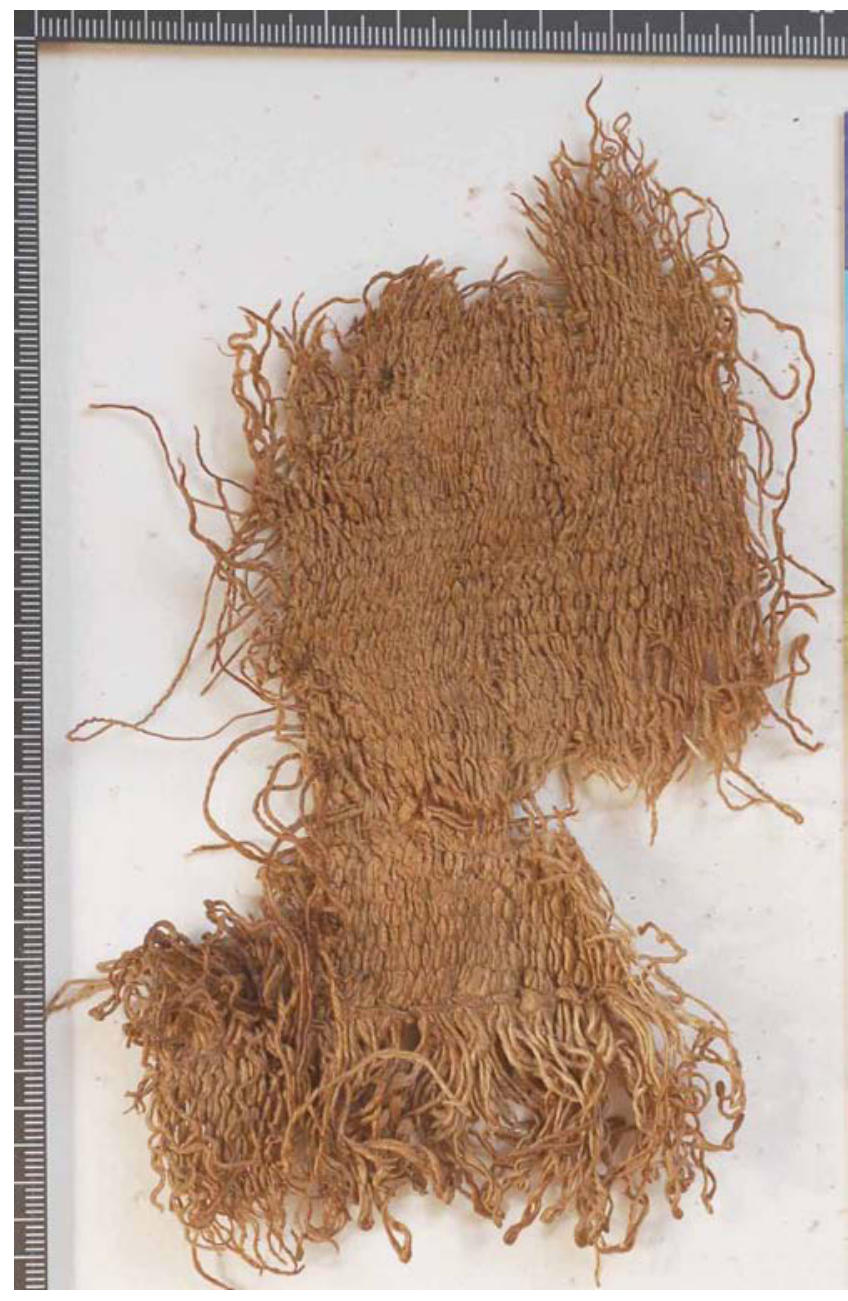

Figure 3. Border with uncut warps: linen (Photo: Fleur Letellier-Willemin (C) Mission archéologique d'El-Deir/ANR OASIS).

two-part tunics, ${ }^{10}$ which have a special herringbone stitch. We have seen a few repairs, darning or patching: they are carefully sewn. The most frequent dimensions of the complete tabbies are about $1 \times 1$ or $1 \times 2$ metres, which recalls the royal Egyptian cubit $(52.50 \mathrm{~cm}) .{ }^{11}$ Bigger tabbies were found in the north-east cemetery: one, incomplete, with warp threads of more than 4 metres and a complete example with two borders of which the warp threads are more than 3 metres (similar to textiles from the tomb of Wah, Middle Kingdom). ${ }^{12}$
Patterns can be sorted into four categories:

- made during warping: for example, blue stripes. To make stripes (warp) and not bands (weft), blue longitudinal warp threads must be set. Several textiles decorated with blue stripes are held in the Metropolitan Museum of Arts (e.g. MMA 07.316.46.6, MMA 90.5.102);

- made during warping and weaving: for example, check-patterned linen textile (half-basket). To make checks one needs coloured warp and coloured weft;

- made during the weaving: with classical undyed selfbands (there are also some openwork and weft patterns similar to chain-like patterns that are sometimes discontinuous) (fig. 4);

- made after the weaving: with cords sewn on borders (neck-openings for example) and with painting on several shrouds.

Most of the linen textiles are undyed but we can find coloured textiles in various shades of brown, red, yellow, orange, pink, black-brown, blue and green-blue (fig. 5). This implies that there were different dyes and different dying techniques. ${ }^{13}$ Analyses of the dyes have not yet been conducted for reasons outwith our control, but it is possible to say that we are dealing with mineral and vegetal dyes. Kharga Oasis supplied ochre and alum (Dominique Cardon mentions Kharga as a source of alum, ${ }^{14}$ while Alfred Lucas and J.R. Harris state that ochres come from the western oa$\left.\operatorname{ses}^{15}\right)$. Some rare whitish fragments appear to have been intentionally bleached.

Many linen shrouds were found in the Christian cemetery. They all have similar dimensions to those of the polytheistic cemeteries ( $2 \times 1$ metres approx.), plain selvedges with the same patterns, simple cut fringes, openwork made by the lack of wefts, additional coloured woollen wefts and two or four "medallions" in the corners made with coloured woollen looped wefts. Up to 11 newly made linen shrouds can be used to wrap a mummy. The quality of flax used to produce them is different from that of the shrouds from the Ptolemaic and Roman tombs. It is of lower quality with irregular threads and low twisting, although the weaving is good. Few linen fragments of high quality were, however, found in the Christian cemetery.

10. About tunics used in Egypt in the Roman period, cf. Pritchard 2006 and Mossakowska-Gaubert 2017.

11. About cloth-weaver cubit, see Hirsch 2013, p. 86-97.

12. Kemp \& Vogelsang-Eastwood 2001, p. 324-335.

13. Cardon 2003, p. 80, and 356.

14. Ibid., p. 29.

15. Lucas \& Harris 1962, p. 236. 


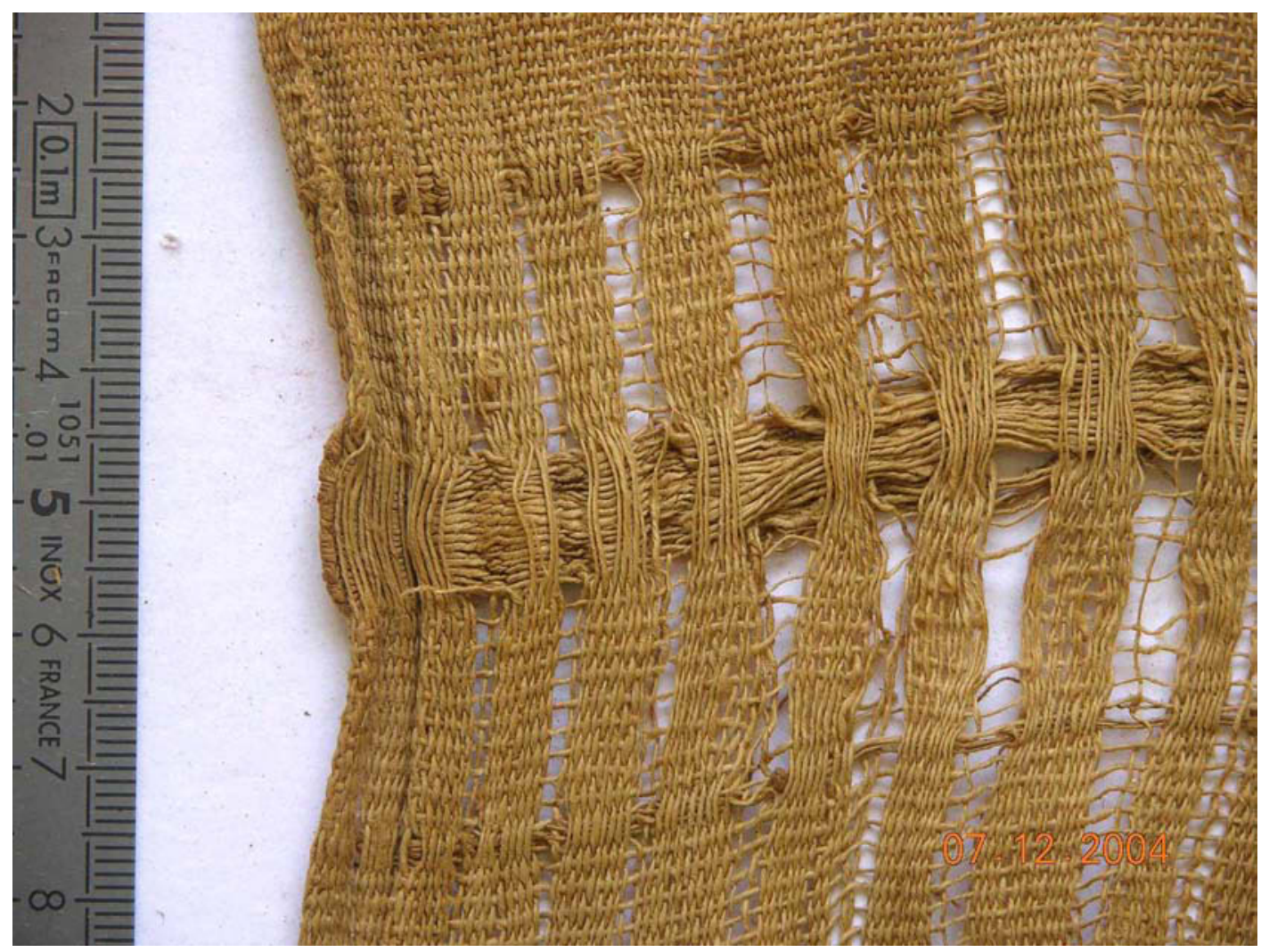

Figure 4. Pattern

with openwork:

linen (Photo:

Fleur Letellier-

Willemin (c) Mission

archéologique d'El-

Deir/ANR OASIS).

Figure 5. Dyed

linen fabrics:

samples (Photo:

Fleur Letellier-

Willemin (C) Mission archéologique d'El-

Deir/ANR OASIS).

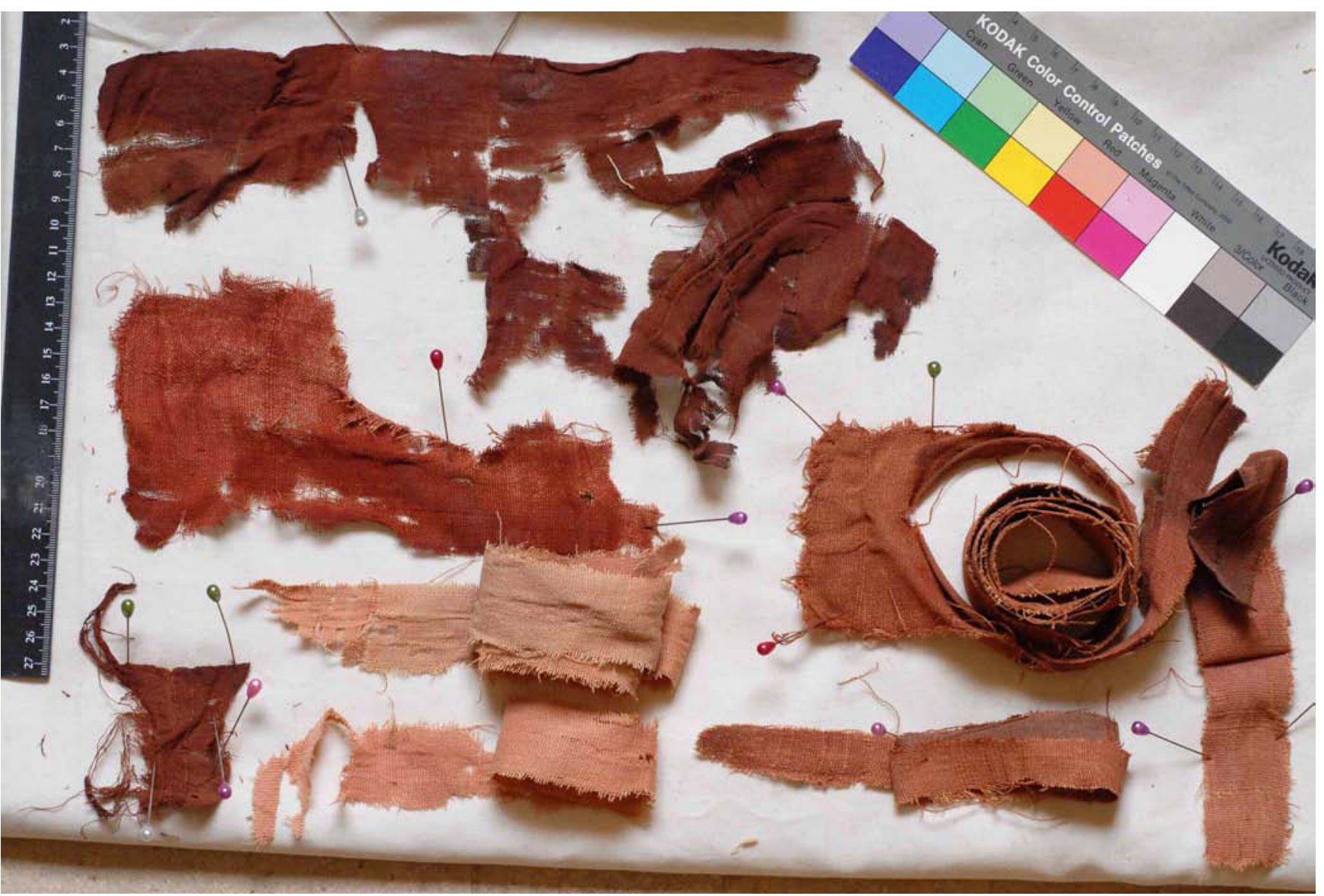


We have also found narrow bands (warp-faced tabby, basket or balanced tabby). Incidentally, the weaving of narrow bands is described in some texts from the Theban area and dated from the beginning of $8^{\text {th }}$ century $\mathrm{AD}$. These were woven by monks on narrow looms. ${ }^{16}$

The linen textiles from other parts of the El-Deir site are plain weave with few colours and little decoration. It is worth remarking that one fragment of linen found in the fortress was dyed in green and red. This is a very significant example that corresponds to another textile and cultural context. Red is a difficult colour to obtain on this material and to do so required a particular dying technique, which only appeared in Egypt during the Roman period. This fragment is associated with some woollen tassels as well as a small fragment of reversible taqueté, which leads us to link these textile novelties from the fortress to those of the Eastern Desert.

\section{Cotton}

We found cotton everywhere we dug and the most important questions are: where does it come from and when was it made? Ten samples have been dated using ${ }^{14} \mathrm{C}$ method: the oldest is from the $1^{\text {st }}$ century $\mathrm{BC}$ and the most recent from the $4^{\text {th }}$ century AD.

The origin of the cotton is complex and, in the case of Kharga Oasis, probably multiple, within a very different context than the Eastern Desert. The knowledge of cotton may have been acquired by the people of the oasis from merchants and travellers moving along the caravan routes out of Sudan and Nubia. ${ }^{17}$ Research into the cultivation and use of cotton in Egypt is in progress. We should mention here the "revised ideas" on Egyptian cotton presented by John-Peter Wild, Felicity Wild and Alan J. Clapham, ${ }^{18}$ as well as studies on cotton textiles from Kellis by Rosanne Livingstone, ${ }^{19}$ Nubian cotton textiles by Elsa Yvanez, ${ }^{20}$ papyrological documentation published by Rogel S. Bagnall, ${ }^{21}$ and a recent publication the Nord Kharga survey textile material by Jana Jones. ${ }^{22}$
All cotton fragments are plain tabbies, weft faced, with reinforced bundled selvedges, thus they are in fact woven in the same way as wool in the Greek tradition, on a warpweighted loom. According to the studies presented by Wild, Wild and Clapham, the presence of the warp-weighted loom in the oasis seems to be connected with local cotton production. ${ }^{23}$

Cotton fibres from El-Deir are spun with a hard irregular twist and irregular diameters. The twist is always S. We find many errors, mainly weft floats, but a few weaves are quite regular, tightly packed and with a high density (fig. 6 ). The quality of the spinning and of the weaving depends on the quality of the fibres, the tools and the experience of the weaver working with a "new" fibre. Cotton thread can also be used for sewing, hemming, darning and patching, even on linen and woollen textiles.

Cotton is used in some other techniques, such as pile fabrics (fig. 7), with symmetrical knots (Ghiordes). ${ }^{24}$ These knots are also used as a discontinuous pattern.

One piece of textile presents a very particular cotton weave. It is of very good quality with three different patterns, like crêpe. We have noticed this in woollen scarves from the Christian cemetery. It implies the weaver was extremely experienced. ${ }^{25}$

We have also found cotton textiles in the padding of mummies from polytheistic cemeteries and incomplete cotton shrouds in the Christian cemetery. Some fragments are woven with a linen warp and a cotton weft. And finally, also in the Christian cemetery, we found a large coat woven with cotton warp and different woollen weft (probably sheep and camel).

Another use for cotton is in making cord. Up to several dozen metres of cord can be found rolled around some mummies, replacing the traditional bandages (or their narrow newer version). Some of the cotton cord is coated. Analyses have confirmed this and indicated the presence of linseed oil and animal fat. We have not found any published example of comparable treatment on cotton cord from other sites.

16. Heurtel 2003-2004, p. 61. Among other references, G. Castel, who studied a "mummy" of a monk from the Theban necropolis, records a linen binding some $60 \mathrm{~m}$ in length by $2.5 \mathrm{~cm}$ wide (Castel 1979, p. 122).

17. Gradel et al. 2012.

18. Wild et al. 2008.

19. Livingstone 2009.

20. Yvanez 2016.

21. Bagnall 2008.

22. Jones 2018.

23. Wild et al. 2008, p. 144.

24. Seiler-Baldinger 1994, p. 111; Livingstone 2009, p. 79.

25. Letellier-Willemin \& Médard 2012. 


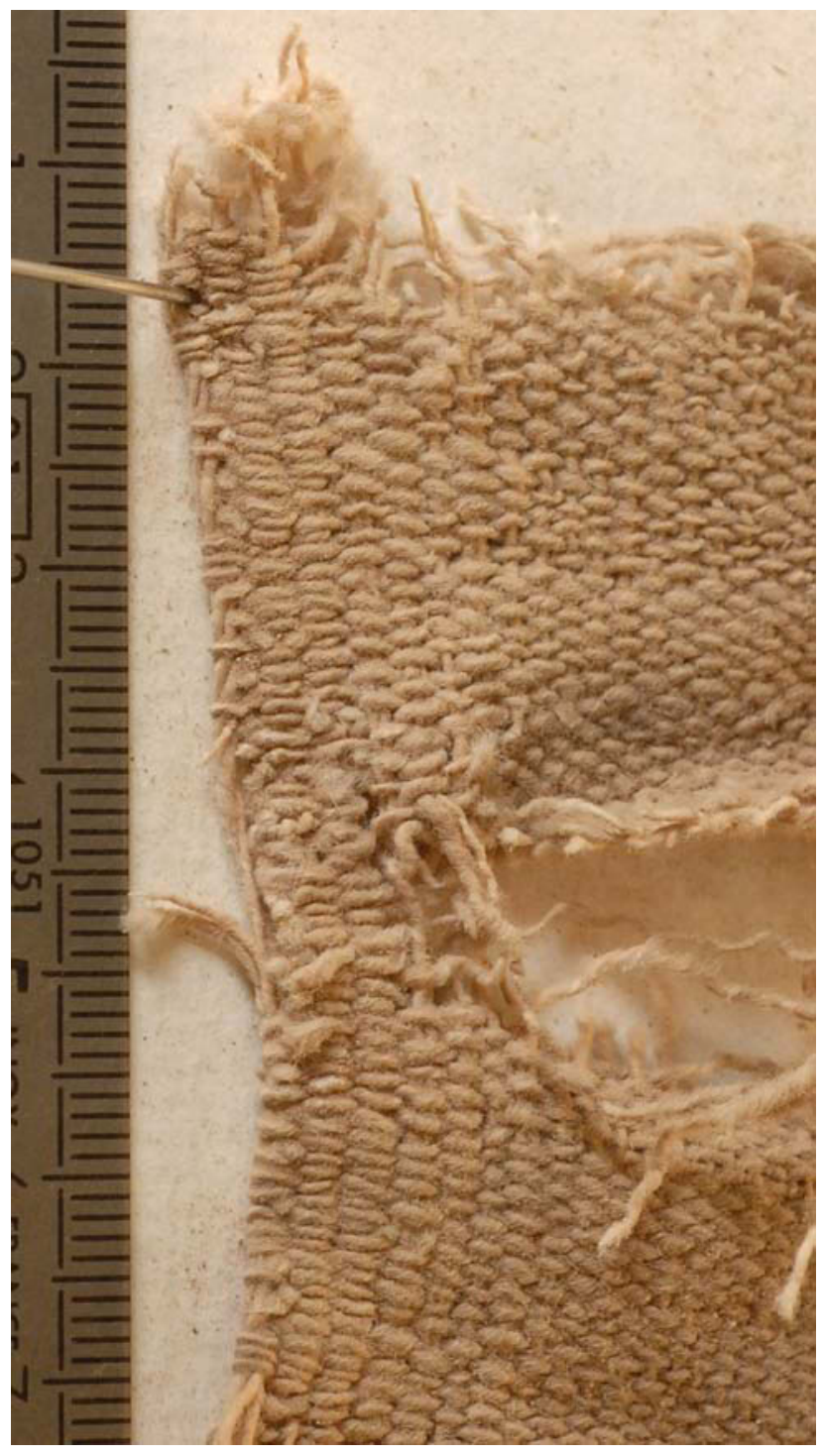

Figure 6. Fragment of a border: cotton fabric (Photo: Fleur Letellier-Willemin (C) Mission archéologique d'El-Deir/ANR OASIS).

\section{Wool}

The woollen textiles come from the Christian cemetery, the workshop of the embalmers, the temple and the fortress. In El-Deir, we found sheep wool with different undyed colours (from white to brown), goat wool, and perhaps camel wool as well. All the threads are $S$ threads except for one, a fine basket weave, with $\mathrm{Z}$ threads dyed in a purple-like colour, which suggests a foreign origin.

Working with wool is generally well mastered. There is an example of a fragment with a density of 32 weft yarns per centimetre and 24 warp yarns per centimetre.

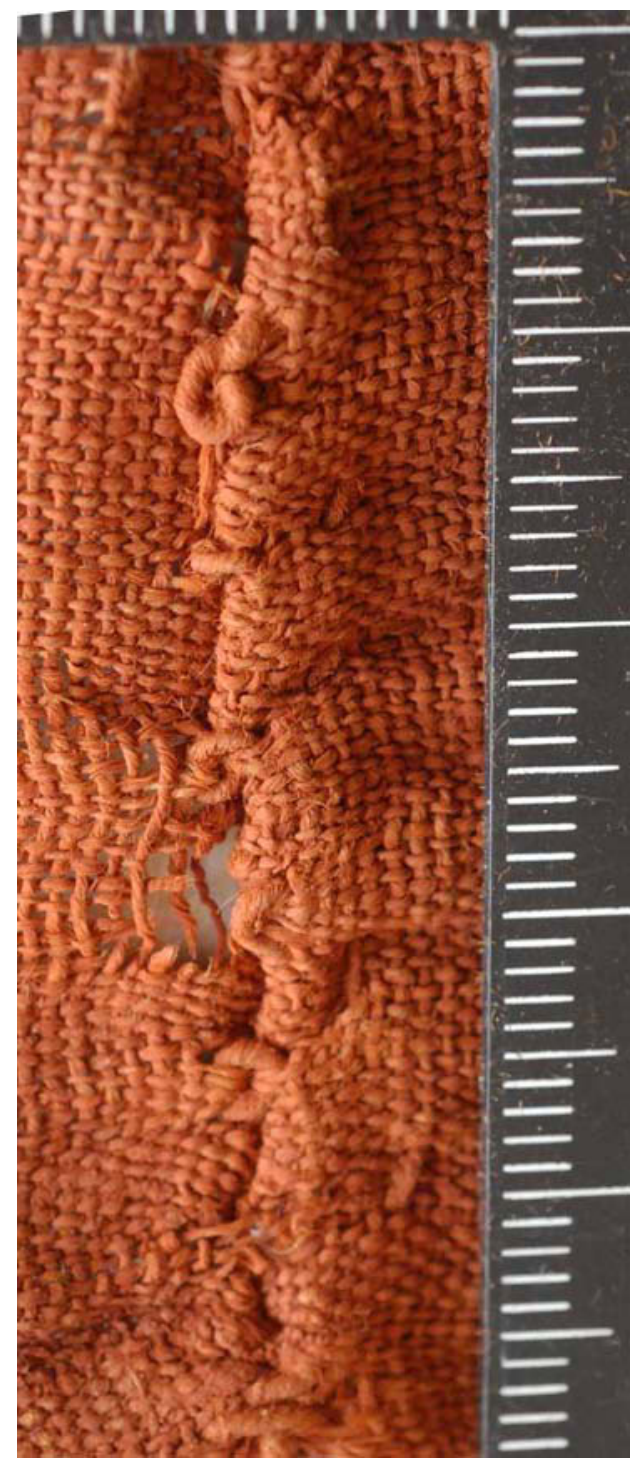

Figure 7. Fragment with piles: cotton fabric (Photo: Fleur Letellier-Willemin (C) Mission archéologique d'El-Deir/ANR OASIS).

Wool is used for the weaving of clothes and accessories. There are two kinds of woollen tunic: made of two parts (Roman type) and woven-to-shape (widespread from the $3^{\text {rd }}$ century AD onwards). We found a woven-to-shape tunic: it is a long undyed tunic with long narrow sleeves. This tunic has been extensively repaired, which involved meticulous needlework that imitated the weaving and respected the appearance of plain weave. The width of the tunic implies the use of a large loom. This tunic has embroidery decoration on the shoulders (fig. 8).

Embroidery is not rare in Kharga, as shown by textiles from the Christian cemetery in Bagawat, near Hibis, ${ }^{26}$ and 


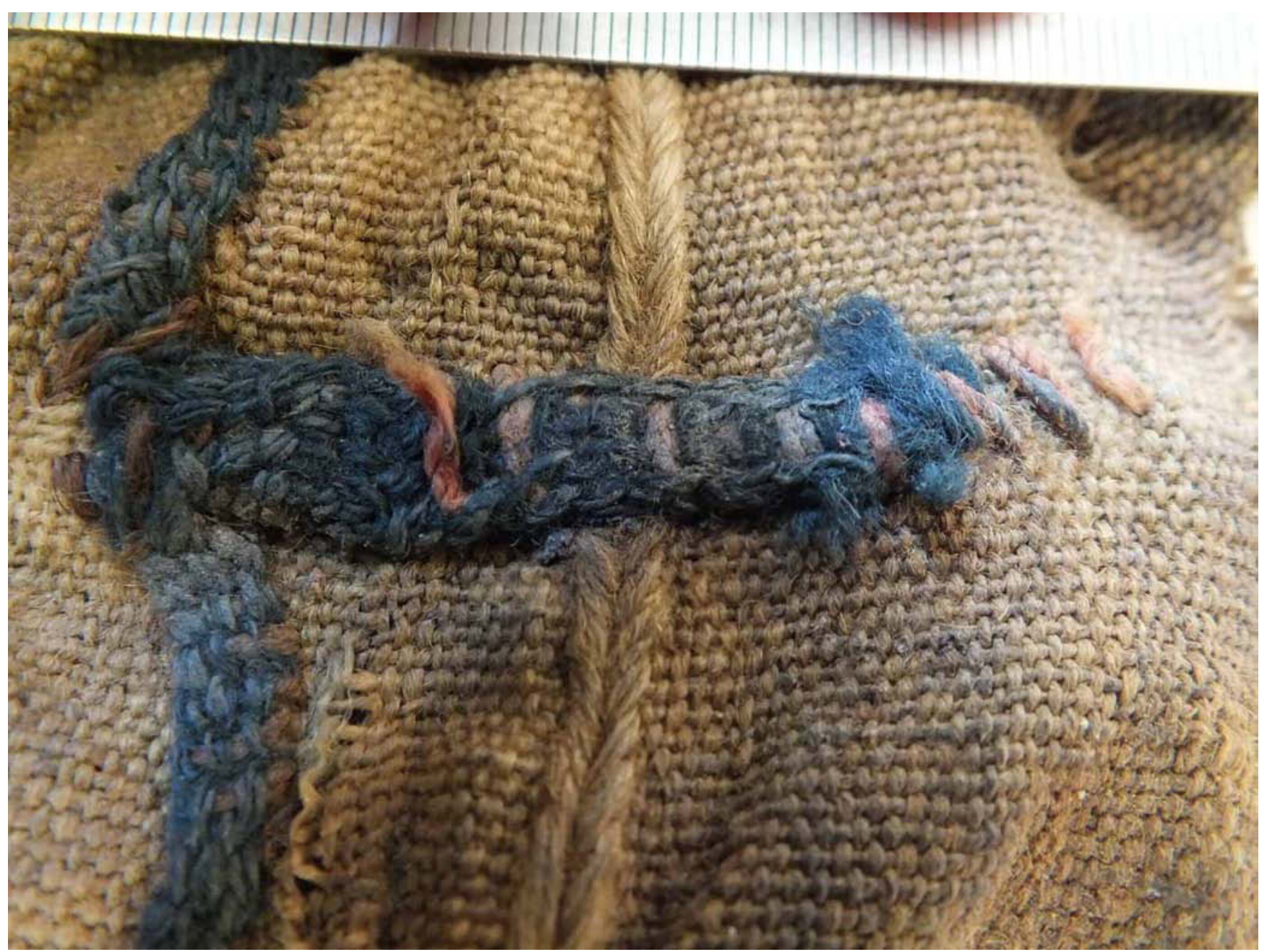

Figure 8. Fragment of a woollen tunic with embroidered motifs on the shoulders (Photo: Fleur Letellier-Willemin (C) Mission archéologique d'El-Deir/ANR OASIS).

a tunic from Dush with its embroidery instead of classical tapestry. ${ }^{27}$ Tapestry and embroidery are of course very different techniques but it is not just a question of technique. When both are possible, what criteria determine the choice between one over the other?

At the same time, tapestry decoration in wool is also attested in the material from the Christian cemetery at ElDeir. It can be seen on a fragment of a "medallion".

Some linen shrouds from polytheistic cemeteries show looped weft patterns in different dyed wools (fig. 9). According to Christina Rigg, these "concentric circles used as a fill pattern" are characteristic of Kharga Oasis. Such finds date to the $1^{\text {st }}$ century AD. Moreover, these patterns are also visible on sarcophagi and on cartonnages found in Roman necropoleis in Egypt. ${ }^{28}$

A few woollen fragments of tapestry were found in the Roman necropoleis of El-Deir. These fragments bear wave patterns, frequently seen on painted friezes of sarcophagi, with the classic colours of Egyptian iconography, such as red, blue, yellow and green. Some wool braids are decorated with a linen pattern.

Many fragments of tunics display clavi. According to the work of Lise Bender Jørgensen, different types of clavi imply the use of different looms. ${ }^{29}$ Certain clavi display crossed warp threads suggesting the use of a vertical loom in their weaving, whereas other clavi have a warp that

27. Letellier-Willemin 2013.

28. Ibid.

29. Bender-Jorgensen 2011. 
is not crossed, suggesting the possible use of a weighted loom. Headscarves are woven with hard twisted threads, making a crêpe look. Comparable scarves were found on a Jewish site near the Dead Sea. ${ }^{30}$

The last example of woollen textiles from a funerary context is a kentrôn, wrapping a newborn baby, found in the Christian cemetery. Other kentrônes are described from Didymoi in the Eastern Desert and from Masada, ${ }^{31}$ while a text from Dakhleh also cites one as a gift.

The fortress has not been excavated until now, but there have been three trial soundings. Some fragments of textiles have been found and they are very important: one is a fragment of taqueté work (fig. 10) and one is of a linen textile dyed red and green. ${ }^{32}$ They reflect new techniques in weaving and dying. Indeed, the Roman military came from a rather different textile universe. ${ }^{33}$ Dated from the $3^{\text {rd }}$ century AD and built under Diocletian, the fortress was probably also a customs post between the oasis, its routes and the Nile Valley. ${ }^{34}$

\section{Final Remarks}

The question to be asked after this review of the material from El-Deir is whether the continuity and changes seen within the field of textiles finds an equivalent in the domains of religion, culture and economy. We can confirm a respect for Pharaonic textile traditions during the Ptolemaic period and very largely in the Roman era. The sobriety of the textiles, the plain linen cloth, the few coloured textiles (whose functions are to be determined moreover), the infrequent and repetitive decoration, are not signs of poverty but of respect for aesthetic criteria and an attachment to long-defined values. Among the categories of textiles from El-Deir, there is one that predominates over 800 years and is defined by constant features throughout that long period. This is a plain linen cloth, roughly $100 \mathrm{~cm}$ by $200 \mathrm{~cm}$ in size that is found on the site and in the cemeteries of all the eras. In consequence, we have opted to use it as a reference textile. It displays an average warp density of 24 to 28 threads per centimetre and weft density of 10 to 12 per centimetre. The threads have a diameter of between 0.3 to $0.4 \mathrm{~mm}$. It requires about 7 to $8 \mathrm{~km}$ of thread for its manufacture. Certain textiles of the site, woven with 60 warp yarns and 20 weft yarns per centimetre, need about $16 \mathrm{~km}$ of thread. In this way, we can calculate the thread

30. Granger-Taylor 2006, p. 121.

31. Cardon 2003b, p. 635.

32. Loc. cit.

33. Mannering 1999.

34. Mattingly et al. 2007, p. 154 .

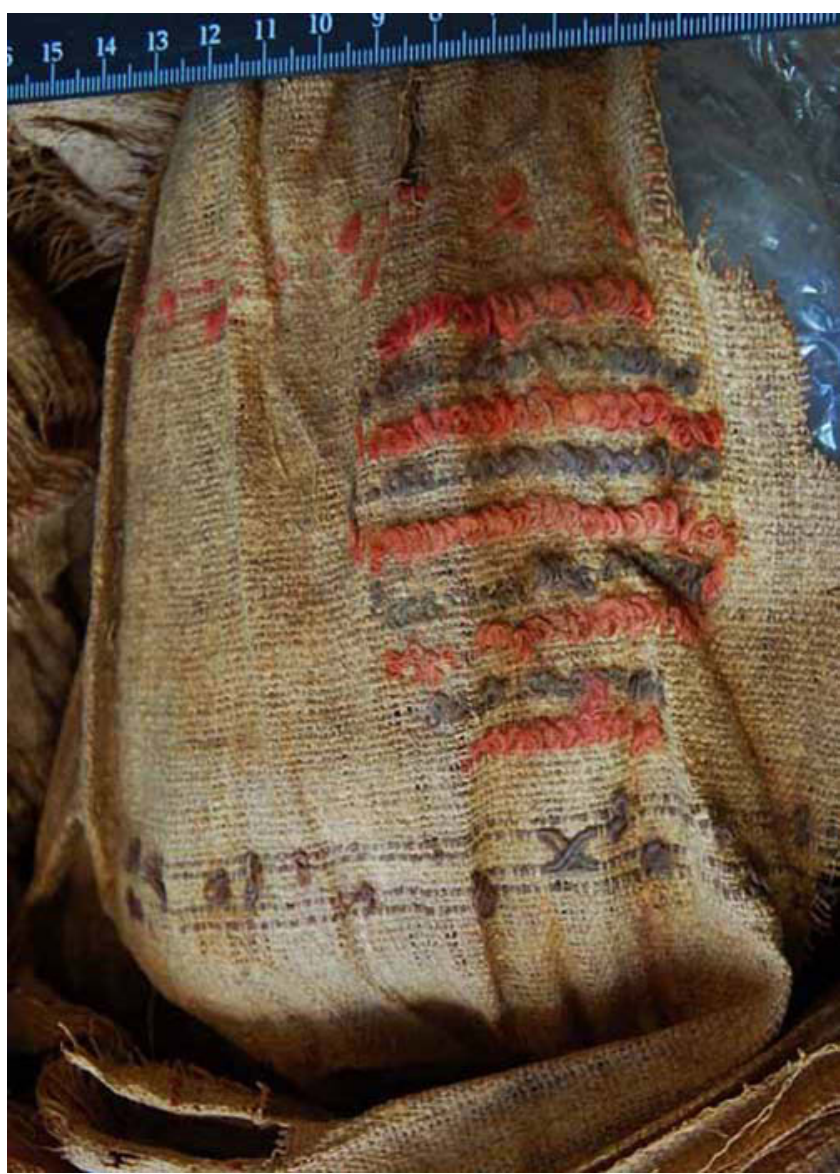

Figure 9. Woollen looped weft pattern on a linen shroud (Photo: Fleur Letellier-Willemin (C) Mission archéologique d'ElDeir/ANR OASIS).

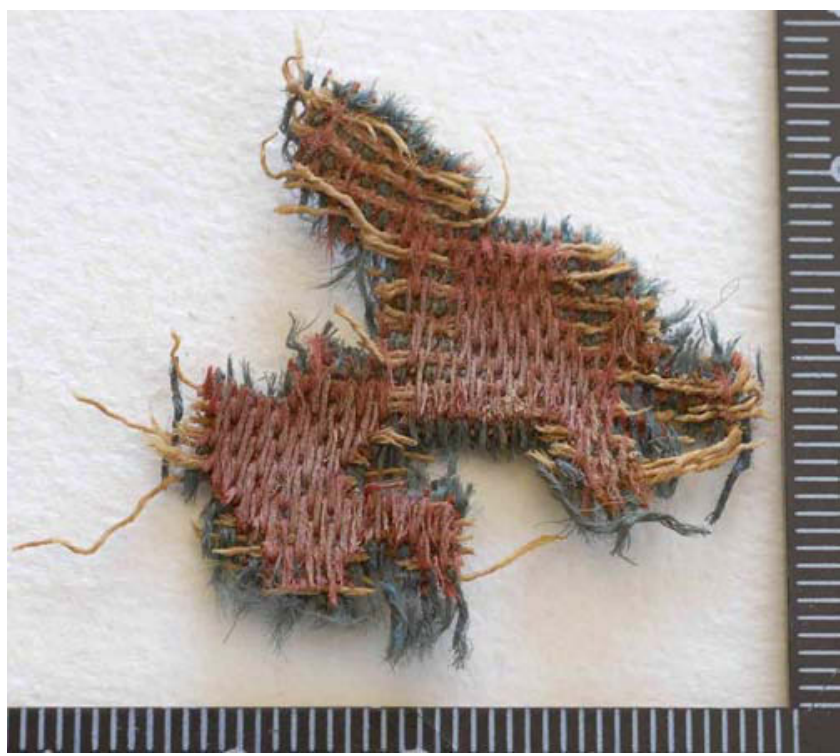

Figure 10. Fragment of a taqueté fabric: wool (Photo: Fleur Letellier-Willemin (C) Mission archéologique d'El-Deir/ANR OASIS). 
necessary for all the cloth present. This sheds a different light upon the material under study and can reveal some basic economic values. The many shrouds discovered in all of the cemeteries of El-Deir raise the possible existence from the $5^{\text {th }}$ century BC until perhaps the $5^{\text {th }}$ century AD of local workshops specialised in their production. ${ }^{35}$

As far as quality is concerned, the presence of some rare but significant textiles are the markers of particular status that is still to be defined, as in the case of a wide binding with two selvedges, a cotton fabric of great quality that is currently unique, and certain cloths of high density used as a support for cartonnage (these re-used everyday textiles inform us of the everyday textile quality).

The textiles of El-Deir allow us to compare the evolution of the three fibres against one another. We must emphasise the predominance of linen, which is the standard fibre until the $3^{\text {rd }}$ century AD. Nonetheless, other fibres appear: cotton towards the end of the $1^{\text {st }}$ century BC-beginning of the $1^{\text {st }}$ century AD, and wool, which is visible above all in textiles from a Christian cemetery ( $4^{\text {rd }}$ century AD and later). We find cotton in everyday textiles, such as tunics, which are then re-used as shrouds. A surprising observation is that cotton cord in the $4^{\text {th }}$ century replaces the traditional bindings without selvedge and the narrow bindings with double selvedge that are characteristic of this period. These cords represent a very large quantity of cotton thread and thus of fibre.

As regards wool fibre from El-Deir, at the beginning of the Roman period some woollen wefts appeared in linen shrouds and then small medallions. The use of this raw material gradually developed in the Roman era: some deceased were wrapped in linen shrouds and woollen clothes at the same time. In the Byzantine period woollen textiles, notably clothing, become predominant. ${ }^{36}$

The observation of all these changes calls up certain questions. In a place like Kharga, what were the conditions needed for innovations to appear and how much time did it take? Where and how did textile innovations appear? For which persons, of what status, and what identity? When did wool and cotton dominate the textile world of El-Deir?

The variety of weaving techniques attested on the site of El-Deir would seem to prove that, at different times, different looms were used: ${ }^{37}$ ground loom, vertical two-beam loom, warp-weighted loom, and tablet loom. It is not always easy to link a type of weaving or decoration to a technique and a tool. Several ways are sometimes imaginable.

Based on archaeological findings, including the textiles, the most prosperous time for the site of El-Deir was during the Ptolemaic period. Research into the textiles of ElDeir contributes to the study of a territory, of agriculture, of livestock and the management of water, for example. Each fibre, made of flax, cotton or wool, is a marker of the interaction between the economy of the region and a common citizen and of the interaction between tradition and change. ${ }^{8}$

The tools used with each fibre, the existence of workshops, specialised or not, and importations are all important questions to be considered, the same questions that we find in the study of ceramics. ${ }^{39}$ The three fibres and the associated weaving techniques reflect the identity of the inhabitants of El-Deir and studying these textiles is like mapping the area and its many routes and crossroads over time.

\section{Bibliographie}

Agut, D. \& Moreno-Garcia, J.C. (2016) L'Égypte des Pharaons. De Narmer à Dioclétien 3150 av. J.-C.-284 apr. J.-C. Mondes anciens, Paris.

Agut-Labordère, D. (2014) “L'orge et l'argent. Les usages monnétaires à Ayn Manawir à l'époque perse", Annales. Histoire. Sciences Sociales 69/1, Paris, p. 75-90.

Bagnall, R.S. (2008) "SB 6.9025, Cotton and Economy of the Small Oasis", Bulletin of the American Society of Papyrologists 45, p. 21-30.

Ballet, P. (1998) "Cultures matérielles des déserts d'Égypte sous le Haut et le Bas-Empire : productions et échanges", in O.E. Kaper (ed.), Life on the Fringe: Living in the Southern Egyptian Deserts during the Roman and early-Byzantine Periods. Proceedings of a Colloquium Held on the Occasion of the 25th Anniversary of the Netherlands Institute of Archaeology and Arabic Studies in Cairo, 9-12 December 1996, Leiden, p. 30-54.

35. Other specialised local workshops are known from the Nile Valley, e.g. Qarara (Sharuna), Middle Egypt: end of $4^{\text {th }}-8^{\text {th }}$ century AD (Huber 2015).

36. Letellier-Willemin 2012.

37. Wild 2015.

38. About the economy of textiles and textile production within the oasis context see also the article by Jennifer Cromwell, in this volume (Cromwell 2020).

39. Ballet 1998. 
Bender Jørgensen, L. (2011) "Clavi and Non-clavi: Definition of Various Bands on Roman Textiles”, in C. Alfarom, Ph. Borgard, J.-P. Brun \& R. Pierobon (eds.), Purpureae Vestes III. Textiles y tintes en la ciudad antigua. Actas del III Symposium Internacional sobre Textiles y Tintes del Mediterráneo en el mundo antiguo (Nápoles, 13-15 de Noviembre, 2008), Valancia-Naples, p. 75-80.

Cardon, D. (2003a) Le monde des teintures naturelles, Paris.

Cardon, D. (2003b) "Chiffons dans le désert : textiles des dépotoirs de Maximianon et de Krokodilô", in H. Cuvigny (ed.), La route de Myos Hormos. L'armée romaine dans le désert oriental d'Egypte. Fouilles de l'Institut français d'archéologie orientale du Caire 48/1, Cairo, p. 619-659.

Cardon, D., Granger-Taylor, H. \& Nowik, W. (2011) "What did they look like? Fragments of Clothing Found at Didymoi: Case Studies", in H. Cuvigny (ed.), Didymoi. Une garnison romaine dans le désert Oriental d'Égypte. Fouilles de l'Institut français d'archéologie orientale du Caire 64, Cairo, p. 273-362.

Castel, G. (1979) "Étude d'une momie copte”, in J. Vercoutter (ed.), Hommages à la mémoire de Serge Sauneron 1927-1976 II: Égypte post-pharaonique. Bibliothèque d'Étude 82, Cairo, p. 121-143.

Cromwell, J. (2020) "Domestic Textile Production in Dakhleh Oasis in the Fourth Century AD", in M. Mossakowska-Gaubert (ed.), Egyptian Textiles and their Production: 'Word' and 'Object' (Hellenistic, Roman and Byzantine Periods). Zea Books 2020, Lincoln, p. 139149. Available at http://digitalcommons.unl.edu/etpwo

Chauveau, M. (1996) "Les archives d'un temple des oasis au temps des Perses, Bulletin de la Société Française d'Égyptologie 137, p. 32-47.

Cook, W.D. \& Brennan, A. (1990) "The Spinning of Fine Royal or Byssos Linen", Archaeological Textiles Newsletter 10, p. 9.

Cortopassi, R., \& Verhecken-Lammens, C. (2007) "Tunics with Loops: ${ }^{14} \mathrm{C}$, Spinning, Weaving, Dyes and Iconography”, in A. De Moor \& C. Fluck (eds.), Methods of Dating Ancient Textiles of the $1^{\text {st }}$ Millennium AD from Egypt and Neighbouring Countries. Proceedings of the 4th conference of the research group 'Textiles from the Nile Valley', Antwerp, 16-17 April 2005, Tielt, p. 139-149.

Gradel, C, Letellier-Willemin, L. \& Tallet, G. (2012) “ 'Une laine bien plus belle et douce que celle des moutons' à el-Deir (oasis de Kharga, Égypte) : le coton au cœur de l'économie oasienne à l'époque romaine", in S. Guédon (ed.), Entre Afrique et Égypte. Relations et échanges entre les espaces au sud de la Méditerranée à l'époque romaine. Scripta Antiqua 49, Bordeaux, p. 119-141.

Granger-Taylor, H. (2006) “Textiles from Khirbet Qazone and the Cave of Letters, Two Burials Sites near the Dead Sea: Similarities and Differences in Find Spots and Textiles Types", in S. Schrenk (ed.), Textiles in situ. Their Find Spots in Egypt and Neighbouring Countries in the First Millenium CE. Riggisberger Berichte 13, p. 113-131.

Guédon, S. (2012) "Voie de mer, voie de terre : les itinéraires de voyage entre l'Afrique Proconsulaire et l'Égypte romaine à travers les sources écrites", in S. Guédon (ed.), Entre Afrique et Égypte.

Relations et échanges entre les espaces au sud de la Méditerranée à l'époque romaine. Scripta Antiqua 49, Bordeaux, p. 45-70.

Heurtel, C. (2003-2004) “Tissages et tissus funéraires”, Grafma Newsletter 7-8, p. 6o-66.

Hirsch, A.P. (2013) Ancient Egyptian Cubits - Origin and Evolution, PhD, University of Toronto.

Available at: https://tspace.library.utoronto.ca/ bitstream/1807/35848/10/Hirsch Antoine P 201306 PhD thesis.pdf (last checked: 28/6/2019).

Hope, C.A. \& Whitehouse, H.V. (2003) "The Gladiator Jug from Ismant el-Kharab”, in G.E. Bowen \& C.A. Hope (eds.), The Oasis Papers 3: Proceedings of the Third International Conference of the Dakhleh Oasis Project. Dakhleh Oasis Project Monograph 14, Oxford, p. 291-310.

Huber, B. (2015) "Qarara : une affaire de linceuls", in A. De Moor, C. Fluck \& P. Linscheid (eds.), Textiles, Tools and Techniques of the 1st Milennium AD from Egypt and Neighbouring Countries. Proceedings of the 8 th conference of the research group 'Textiles from the Nile Valley', Antwerp, 4-6 October 2013, Tielt, p. 13-25.

Jones, J. (2018) “Textiles”, in C. Rossi \& S. Ikram (eds.), North Kharga Oasis Survey. British Museum Publications on Egypt and Sudan 5, Leuven, p. 541-549.

Kajitani, N. (2006) "Textiles and Their Context in the Third to the Fourth Century CE Cemetery of alBagawat, Kharga Oasis, Egypt, from the 1907-1931 Excavations by the Metropolitan Museum of Arts, New-York", in S. Schrenk (ed.), Textiles in situ. Their Find Spots in Egypt and Neighbouring Countries in the First Millenium CE. Riggisberger Berichte 13, p. 95-112.

Kamp, B.J. \& Vogelsang-Eastwood, G. (2001) The Ancient Textile Industry at Amarna. Egypt Exploration Society Excavation Memoir 68, London. 
Letellier-Willemin, F. (2012) "Contribution of Textiles as Archaeological Artefacts to the Study of the Christian Cemetery", in R.S. Bagnall, P. Davoli \& C.A. Hope (eds.), The Oasis Papers 6: Sixth International Conference of Dakhleh Oasis Project. Dakhleh Oasis Project Monograph 15, Oxford, p. 491-495.

Letellier-Willemin, F. (2013) "The Embroidered Tunic of Dush. A New Approach”, in A. De Moor \&

C. Fluck (eds.), Drawing the Threads Together. Textiles and Footwear of the 1st Millennium AD from Egypt. Proceedings of the 7 th conference of the research group 'Textiles from the Nile Valley', Antwerp, 7-9 October 2011, Tielt, p. 22-33.

Letellier-Willemin, F. \& Médard, F. (2012) “Techniques inattendues dans un fragment textile en coton du site d'El Deir, oasis de Kharga, désert occidental égyptien”, Archaeological Textiles Review 54, p. 62-71.

Livingstone, R. (2009) "Late Antique Household Textiles from the Village of Kellis in the Dahkleh Oasis", in A. De Moor \& C. Fluck, Clothing the House. Furnishing Textiles of the 1st Millennium AD from Egypt and Neighbouring Countries. Proceedings of the 5 th conference of the research group 'Textiles from the Nile Valley', Antwerp, 6-7 October 2007, Tielt, p. 73-85.

Mannering, U. (1999) "Roman Garments from Mons Claudianus”, in D. Cardon \& M. Feugères (eds.), Archéologie des textiles des origines au $V^{e}$ siècle. Actes du colloque de Lattes, oct. 1999. Monographies Instrumentum 14, Montagnac, p. 283-289.

Mattingly, D., Lahr, M., Armitage, S., Barton, H., Dore, J., Drake, N., ... Sterry, M. (2007) "Desert Migrations: People, Environment and Culture in the Libyan Sahara", Libyan Studies 38, p. 115-156. Available at: http://doi.org/10.1017/ $\underline{\text { So263718900004283 }}$

Mossakowska-Gaubert, M. (2017) “Tunics Worn in Egypt in Roman and Byzantine Times: the Greek Vocabulary", in S. Gaspa, C. Michel \& M.-L. Nosch (eds.), Textile Terminologies from the Orient to the Mediterranean and Europe 1000 BC - AD 10oo. Zea Books 56, Lincoln, p. 321-345. Available at: https:// digitalcommons.unl.edu/texterm/20/
Pritchard, F. (2006), Clothing Culture: Dress in Egypt in the First Millennium AD. Clothing from Egypt in the collection of The Whitworth Art Gallery, The University of Manchester, Manchester.

Reddé, M. (1992) Le Trésor de Douch (Oasis de Kharga). Documents de fouilles de l'Institut français d'archéologie orientale au Caire 28, Cairo.

Riggs, C. (2005) The Beautiful Burial in Roman Egypt. Art, Identity, and Funerary Religion. Oxford Studies in Ancient Culture and Representation, Oxford.

Seiler-Baldinger, A. (1994) Textiles. A classification of techniques. Bathurst NSW.

Tallet, G., Bravard, J.-P., Guédon, S. \& Mostafa, A. (2012) "The survey Project at El-Deir, Kharga Oasis: First results, New Hypotheses", in R.S. Bagnall, P. Davoli \& C.A. Hope (eds.), The Oasis Papers 6: Sixth International Conference of Dakhleh Oasis Project. Dakhleh Oasis Project Monograph 15, Oxford, p. 349-362.

Wagner, G. (1987) Les oasis d'Égypte à l'époque grecque, romaine et byzantine d'après les documents grecs. Bibliothèque d'Étude 100, Cairo.

Wild, J.P., Wild, F. \& Clapham, A. (2008) "Roman Cotton Revised”, in C. Alfaro \& L. Karali (eds.), Purpureae vestes II. Vestidos, textiles y tintes: estudios sobre la producción de bienes de consumo en la Antigüedad : actas del II symposium internacional sobre textiles y tintes del Mediterráneo en el mundo antiguo (Atenas, 24 al 26 de noviembre, 2005), Valencia, p. 143-147.

Wild, J. P. (2015) “A Heddle from Qasr Ibrim”, in A. De Moor, C. Fluck \& P. Linscheid (eds.), Textiles, Tools and Techniques of the 1st Millennium AD from Egypt and Neighbouring Countries. Proceedings of the 8th conference of the research group 'Textiles from the Nile Valley', Antwerp, 4-6 October 2013, Tielt, p. 143-146.

Yvanez, E. (2016) "Spinning in Meroitic Sudan: Textiles Production Implements from Abu Geili”, Dotawo: A Journal of Nubian Studies 3, Article 9. Available at: http://digitalcommons.fairfield.edu/djns/vol3/iss1/9 